\title{
Psycholinguistics of Virtual Communication in the Context of the Dependence on Social Networks*
}

\section{Психолінгвістика віртуальної комунікації в контексті залежності від соціальних мереж**}

Olga Kaminska ${ }^{1}$

Dr. in Psychology, Professor
Ольга Камінська ${ }^{1}$

доктор психологічних наук, професор

E-mail: kaminolga1@gmail.com orcid.org/0000-0003-4295-8877

Researcher ID: H-2503-2019

Yuri Stezhko ${ }^{2}$

Ph.D. in Pedagogy,

Assistant Professor
Юрій Стежко ${ }^{2}$

кандидат педагогічних наук, доцент

E-mail: istezhko@ukr.net

orcid.org/0000-0002-0226-8081

\section{Liudmyla Gliebova ${ }^{3}$}

Ph.D. in Philology,

Assistant Professor
Людмила Глєбова ${ }^{3}$

кандидат філологічних наук, доцент

$\begin{gathered}\text { E-mail: gleboval1980@gmail.com } \\ \text { orcid.org/0000-0001-8865-7442 }\end{gathered}$
.

\footnotetext{
* This study is done within the framework of the State project and finance support of the Ministry of Education and Science of Ukraine (Registration number 0119U100726).

** Дослідження виконане в рамках Держбюджетного проекту за фінансової підтримки Міністерства освіти і науки України (Реєстраційний номер 0119U100726).
} 
${ }^{1}$ Rivne State University of the Humanities, Department of General Psychology and Psychological Diagnostics

12, Stepan Bandera Str., Rivne, Ukraine, 33000

${ }^{2}$ National Aviation University

1, Cosmonaut Komarov Str., Kyiv, Ukraine, 03058

${ }^{3}$ Centralukrainian National Technical University 8 , Universitetsky Str., Kropyvnytsky, Ukraine, 25006
${ }^{1}$ Рівненський державний гуманітарний університет, кафедра загальної психологї та психодіагностики $\square$ вул. Степана Бандери, 12, м. Рівне, Україна, 33000

${ }^{2}$ Національний авіаційний університет

просп. Космонавта Комарова, 1, м. Київ, Україна, 03058

${ }^{3}$ Центральноукраӥнський наиіональний технічний університет

просп. Університетський, 8, м. Кропивницький, Україна, 25006

Original manuscript received September 25, 2018

Revised manuscript accepted March 25, 2019

\begin{abstract}
The article deals with the problem of determining psychological peculiarities of virtual communication of people, who in a great degree are characterized by dependence on social networks. The author of the article has done a comparative analysis of the peculiarities of cyber-communication of addicts and other Internet users. There were analyzed gender differences of virtual communication. It was established that in the contemporary society virtual communication had become more widespread especially if to analyze it according to the latest information technologies. In such a way the process of interpersonal communication is gradually supplanted by virtual means of transmitting information. The specificity of virtual communication was especially emphasized when the person used social networks which served to maintain contacts, to find like-minded people, to express emotional states, including those ones which were considered unacceptable by the society. There were determined psycholinguistic features of virtual communication in the Internet environment: psycholinguistic presuppositions, psycholinguistic semantic presuppositions, pragmatic, psycho-linguistically marked presuppositions. It was underlined that psycholinguistic presupposition is a special kind of logical mastering of virtual information, cognitive explication of frames by means of actualization of a common fund of knowledge of participants in communication about the world, its organization, the place of a person in it and others. Also, in the Internet environment psycholinguistic semantic presuppositions often take place. Them we'll analyze as a certain semantic component of the message (statement, judgment), the inaccuracy of which in a particular situation
\end{abstract}


makes the message abnormal or inappropriate. It was emphasized that in the space of virtual communication, the pragmatic, psycho-linguistically marked presupposition, which are a component of the message, the speech genre, and discourse (or a text), are directly related to subjective factors of Internet communication (orientation in different situations of virtual communication, actualization of social, cognitive, gender, etc., characteristics of people in one communicative act), the absence of which converts a message, speech genre, discourse (or a text), virtual communication in general into inappropriate - such as insincere, unnatural, provocative, that do not conceal positive conditions, which make a success in a whole.

Key words: virtual communication, cyber-communication, internet communication, interaction, psycholinguistic presuppositions, psycholinguistic semantic presuppositions, pragmatic, psycho-linguistically marked presuppositions.

\section{Вступ}

У сучасному суспільстві віртуальна комунікація набуває все більшого поширення у зв'язку із впровадженням новітніх інформаційних технологій. Таким чином, безпосереднє міжособистісне спілкування поступово витісняється віртуальними засобами передавання інформації. Специфіка віртуальної комунікації особливо яскраво виявляється у разі використання особистістю соціальних мереж, що слугують для підтримки контактів, пошуку однодумців, експлікації емоційних станів, в тому числі - й тих, що соціумом вважаються неприйнятними. Значущих відмінностей віртуальна комунікація порівняно 3 безпосереднім «живим» спілкуванням набуває у випадку наявності в особистості ознак інтернет-залежності, що передбачає зміну спрямованості з реального життя в інтернет-середовище. Враховуючи ці моменти, актуальність дослідження зумовлюється як тенденцією до поширенням інтернетадикції, так і появою нових специфічних особливостей віртуальної комунікації, що потребують подальшого вивчення.

Особливості віртуальної комунікації інтернет-залежних осіб потребують подальших досліджень, в тому числі, з метою виявлення специфіки такого роду взаємодії, та тих аспектів, які приваблюють користувача, змушують його надавати перевагу віртуальному спілкуванню, що, в свою чергу, $є$ корисним для розробки психопрофілактичних та корекційних програм, спрямованих на подолання інтернет-адикції. 
Сучасними вченими досліджувалися різні аспекти віртуальної комунікації. Так, Н. Чіонова (Чионова, 2012) стверджує, що комп'ютерні комунікації створюють нову сферу інформаційного впливу, що зумовлює виникнення незвичних видів суспільних відносин. Віртуальна комунікація може бути як комп'ютерноопосередкованою, так i такою, що здійснюється в мережі. Окрім віртуального спілкування (комунікації в мережі) вона включає односпрямовану (внутрішньоособистісну) віртуальну комунікацію, в якій відсутній компонент міжособистісної взаємодії, а передача інформації відбувається від мережі до неперсоніфікованого користувача.

Характеризуючи процес спілкування в інтернеті, 3. Зав'ялова (Завьялова, 2011) використовує поняття віртуальної особистості, розуміючи під ним результат реконструкції в комунікативному просторі мережі справжнього чи придуманого образу, онтологія якого задається реальним суб'єктом. Така особистість в мережі розпочинає симулятивний діалог - результат симуляції конструктивного діалогу, що характеризується відсутністю спрямованості на діяльність.

Інтегративну модель ідентичності розробила Н. Антонова (Антонова, 2010). Дана модель є ефективною у випадку здійснення емпіричних досліджень особливостей інтернет-комунікації, при цьому вченою були виділені такі компоненти ідентичності, як змістовий, ціннісно-мотиваційний та оціночний.

Специфіку створення віртуального образу «Я» у користувачів інтернету досліджувала А. Коваленко (Коваленко, 2012). Вчена стверджує, що сучасний Web розкриває перед особистістю багато нових можливостей, однією $з$ яких є змога задовольняти соціально неприйнятні потреби. Рефлексія мотивів самопрезентації в інтернеті через створення віртуального образу «Я», з одного боку, дозволяє особистості розкрити свої приховані сторони, а, з іншого, призводить до заглиблення у віртуальний світ.

Аналізом специфіки інтернет-культури та комунікативного процесу, що здійснюється в мережі, займалась Н. Чудова (Чудова, 2002), яка виділяє наступні їі психологічні особливості: відбувається категоризація суб'єктів взаємодії відповідно до категорій «своє» та «чуже»; в мережі панують «свої» специфічні норми та правила, відмінні від загальноприйнятих в соціумі, що змушує особистість 
виробляти нові моделі поведінки, перебуваючи в мережі; простір інтернету дає неабиякі можливості для реалізації міфологічної складової образу «Я»; інтернет дозволяє людині побудувати ідеальний образ світу, в якому вона хотіла б існувати. Інтернет надає можливість поєднати комунікацію i автокомунікацію: тексти, що посилаються іншому, одночасно стають доступними й адресату i адресанту. Ще однією особливістю спілкування в мережі $є$ пристрасть до обговорень, що реалізується в участі у форумах, обміну враженнями в чатах тощо. Також особистість, встановлюючи комунікативні зв'язки в мережі, часто використовує «нік», що $\epsilon$ додатковим способом самовираження, оскільки в стислому вигляді дозволяє їй донести до інших користувачів інформацію, необхідну для презентації. Важливою властивістю інтернет-комунікації $€$ анонімність, що дозволяє особистості вільно почуватися та розкривати ті якості, які вона не дозволяє собі виявляти в реальному житті.

Дослідження комунікативних характеристик інтернет-мережі здійснювала О. Арестова (Арестова, 1996). Вчена встановила, що ця форма спілкування поєднує в собі властивості діалогу, полілогу i монологу, а також усної та письмової мови. Використання інформаційних технологій $€$ новим рівнем опосередкування мисленнєвої, комунікативної, виконавської та творчої діяльності особистості та викликає зміни в операційно-технічній, мотиваційноособистісній i афективній сторонах діяльності. У випадку здійснення роботи в мережі значно знижується дія захисних механізмів особистості, згасає зовнішня соціально престижна мотивація, виникає ефект анонімності. Однак, спілкування в мережі характеризується неабиякою опосередкованістю, що призводить до відчуження інформації, що сприймається. Використання дискантних засобів комунікації перебудовує сферу сприйняття i категоризації суб'єктом часових та просторових співвідношень комунікативного середовища.

Інша вчена, К. Батаєва (2011) стверджує, що кіберкомунікації притаманні такі властивості, як відтермінованість, дистанційованість та відстороненість щодо учасників процесу спілкування. Соціальна мережа при цьому постає не діяльнісною платформою, на якій реалізується особистість, а об'єктом споглядання. 
На таку властивість віртуальної комунікації, як іiі висока інтерактивність, неодноразово звертають увагу (Argaman, 2010; Cirelli, Dickinson \& Poirier, 2015; Белинская, 2013). Вчені зазначають, що інтерактивність дає можливість вступати в діалог 3 аудиторією та отримувати від неї зворотній зв'язок, що, в свою чергу, забезпечує як швидке передавання інформації широкому колу осіб, так і активне іiі обговорення. Також дослідниця виділяє такі особливості кіберкомунікації, як динамічність, процесуальність, персоніфікованість, ситуативна зумовленість, конотативність, соціальна i культурологічна маркованість. Наголошується, що в різних типах дискурсу ці властивості виявляються досить по-різному, і саме це дозволяє визначати їх як мовленнєво-поведінкову систему.

Так, основні типи поведінки в інтернеті визначила Т. Вакуліч (2006): обсесивно-пошуковий тип (спрямований на безпредметний пошук нової інформації, без прагнення отримати результат); компенсаторний тип (спрямований на компенсацію потреби у спілкуванні); емоційно-залежний тип (зорієнтований на перебування в мережі для підтримки бажаного рівня психічної активності та регулювання емоційного стану); комунікативний тип (спрямований на урізноманітнення спілкування як необхідну умову прискорення реальної комунікації); кіберсексуальний тип (зумовлений пошуком в інтернеті сексуальної інформації).

Незважаючи на достатню кількість публікацій, присвячених аналізу особливостей кіберкомунікації в цілому, специфіка взаємодії в інтернет-середовищі осіб, що страждають на залежність від соціальних мереж, залишається недостатньо розкритою. Враховуючи це, метою дослідження $\epsilon$ аналіз психологічних особливостей віртуальної комунікації осіб, яким притаманні ознаки залежності від соціальних мереж.

Отже, завданнями дослідження є: 1. Опис психологічних змін, викликаних розвитком адикції від соціальних мереж. 2. Виявлення специфічних особливостей віртуальної комунікації інтернетзалежних осіб порівняно з іншими користувачами. 3. Встановлення гендерних відмінностей віртуальної комунікації. 4. Ураховуючи отримані результати проведеного емпіричного дослідження, виокремити психолінгвістичні характеристики віртуальної комунікації в інтернет-середовищі. 


\section{Методи та методики дослідження}

У процесі дослідження застосовувалися загальнотеоретичні методи: міждисциплінарний аналіз і синтез психологічної та лінгвістичної літератури 3 проблем дослідження; порівняння, систематизація, узагальнення, інтерпретація наявних теоретичних підходів; аналітична індукція; аналітичне порівняння при аналізі якісних даних. Було використано також сукупність емпіричних методів: тестування (авторська методика дослідження видів інтернет-залежності), бесіда, спостереження, психолінгвістичний аналіз висловлювань, контент-аналіз, інтент-аналіз. Для обробки результатів емпіричного дослідження застосовано метод математичної статистики $\chi^{2}$-критерій Пірсона. Інформація щодо апробації авторської методики та іiі текст наведений в монографії (Камінська, 2015). При підготовці статті використовувалась шкала «Залежність від соціальних мереж» розробленої методики.

Дослідження проводилось на базі Рівненського державного гуманітарного університету протягом 2015-2018 р. та охопило 378 осіб віком 17-22 роки.

\section{Результати та дискусії}

При аналізі результатів авторської методики дослідження видів інтернет-залежності було виявлено 6,4\% респондентів, яким притаманні ознаки залежності від соціальних мереж. Їм властиве сприйняття соціальної мережі як важливої частини свого життя. Особистість кожного дня відвідує свою сторінку, часто змінює статуси, оновлює фото, активно цікавиться новинами та тим, що відбувається у іiі віртуальних друзів. Коли ж вона не має можливості вийти в інтернет, то відчуває значну напругу, не може зосередитися на чомусь іншому, оскільки подумки постійно повертається до того, що зараз відбувається в соціальній мережі, хто заходив на іiі сторінку, хто із віртуальних друзів зараз знаходиться онлайн тощо. Це є ознакою компульсивної поведінки та вказує на те, що надмірна захопленість соціальною мережею знижує якість життя особистості, оскільки в неї не вистачає часу на безпосереднє спілкування 3 друзями, прогулянки тощо, що призводить до виснаження та 
погіршення стану здоров'я. Для прикладу можна навести такі висловлювання респондентів: «Якби я міг утекти від реальності, то обрав би для цього соціальну мережу, тому що лише там я можу вільно спілкуватися», «Комфортно я почуваю себе лише в соціальній мережі», «Коли я в мережі, то можу спілкуватись, використовуючи «фейкову» сторінку - там я такий, яким хотів би бути», «Віртуальні друзі заміняють мені реальних, тому що мені важко знайомитись $з$ людьми».

Такі респонденти характеризують свою комунікацію в мережі як відмінну порівняно із безпосереднім «живим» спілкуванням, стверджують, що надають перевагу віртуальній взаємодії, оскільки почуваються в інтернеті безпечніше, можуть бути собою, мають можливість реалізувати соціально несхвалювані мотиви (агресивність, ворожість, сексуальність тощо).

Контент-аналіз дозволив встановити, що у випадку віртуальної комунікації у респондентів переважають такі дискурси: потреба (33,0\%), нестримне бажання $(27,3 \%)$, напруга $(12,4 \%)$, зосередженість $(10,2 \%)$, безкарність $(8,7 \%)$, зміна $(6,4 \%)$, доступність $(2,2 \%)$.

Інтент-аналіз дав змогу здійснити поглиблене дослідження отриманої інформації та конкретизувати виявлені дискурси: фрустрована потреба (в спілкуванні (16,0\%), у прийнятті $(11,2 \%)$, у повазі (5,7\%)), компульсивність (30,0\%), астенічні емоції $(14,6 \%)$, концентрація на віртуальній реальності $(8,2 \%)$, агресивні тенденції $(5,4 \%)$, «віртуальне Я» $(4,6 \%)$, «відкритість» інтернету для користувача $(3,8 \%)$.

Відповідно, спілкування в соціальній мережі сприймається як засіб задоволення фрустрованих потреб; супроводжується значною емоційною напругою; займає домінувальне місце в думках особистості; дає можливість продемонструвати «віртуальне Я»; обирається через свою доступність.

Пограничні показники залежності від соціальних мереж властиві 20,3\% оптантам, які схильні до виникнення адикції, оскільки мають відповідні передумови до цього, такі як соціальна ізоляція, нездатність підтримувати гармонійні соціальні контакти, високий рівень тривожності та низький рівень самооцінки, що створюють неабиякі бар'єри на шляху до побудови міжособистісних контактів. Таким чином, потреба в спілкуванні виявляється 
фрустрованою, що змушує особистість шукати інші шляхи іiі задоволення, звертаючись з цією метою саме до соціальної мережі. Для ілюстрації наведемо такі висловлювання: «Спілкування в інтернеті допомагає мені не почуватися самотнім», «Я почуваю себе щасливим лише в соціальній мережі», «Спілкування в мережі стає особливо привабливим тоді, коли реальна взаємодія перестає приносити задоволення».

За допомогою контент-аналізу були виділені такі дискурси: задоволення $(60,8 \%)$, втеча $(12,7 \%)$, свобода $(10,3 \%)$, спрощеність $(8,5 \%)$, безконтактність $(5,7 \%)$.

Інтент-аналіз дозволив виділити такі дискурси: втіха (від спілкування $(27,3 \%)$, отримання «лайків» $(25,8 \%)$, перегляду розважальних постів та відео $(7,7 \%))$, витіснення проблем, неприємної реальності $(15,4 \%)$, відсутність контролю з боку інших $(12,5 \%)$, згорнутість висловлювань, емоційних проявів («смайлів») (7,7\%), відсутність необхідності вступати у прямі контакти (3,6\%).

Відповідно, респонденти, яким $є$ властивими пограничні ознаки залежності від соціальних мереж, характеризують віртуальну комунікацію як згорнуту; насичену позитивними емоціями; засіб забути про проблеми та конфлікти повсякденного життя; як середовище, позбавлене контролюючої інстанції; альтернативний спосіб задоволення потреби у спілкуванні.

Відсутність залежності від соціальних мереж демонструють $73,3 \%$ оптантів, які час від часу звертаються до соціальної мережі 3 метою підтримання стосунків зі знайомими людьми, що знаходяться від них на відстані. Таким чином, мережа слугує не для створення віртуального середовища для спілкування, а для підтримки реальних взаємостосунків. Респонденти так характеризують свою комунікацію в мережі: «Спілкування в інтернеті - викривлене та несправжнє, воно не може зрівнятися з безпосередніми контактами», «Віртуальні друзі - це вигадка», «Я почуваю себе щасливим, лише маючи можливість спілкуватися 3 іншими в реальному житті», «В соціальній мережі можна побачити багато нового у знайомих та нагадати про себе».

За результатами контент-аналізу виділено такі дискурси: розвага $(55,0 \%)$, час $(17,5 \%)$, інформація $(12,2 \%)$, «як усі» $(9,8 \%)$, новини $(5,5 \%)$. 
Поглиблене вивчення висловлювань респондентів, проведене за допомогою інтент-аналізу, дозволило виокремити такі дискурси: отримання задоволення від відвідування сторінок друзів $(22,3 \%)$, знайомства 3 новими людьми $(19,6 \%)$, перегляду розважальних постів та відео (10,4\%), обговорення подій $(12,7 \%)$; засіб «вбити час» $(6,3 \%)$, отримання нової інформації про віртуальних друзів (6,4\%), суспільні події (5,0\%); прагнення користуватися соціальними мережами, оскільки так роблять усі $(11,7 \%)$; бути в курсі новин своєї групи (5,5\%).

Таким чином, особи, яким не є властивими ознаки залежності від соціальних мереж, оцінюють віртуальну комунікацію як таку, що дозволяє підтримувати взаємодію з людьми, з якими вже існують реальні контакти; знайомитись 3 новими людьми для встановлення безпосередньої взаємодії в подальшому; як засіб для розваги та заповнення вільного часу; джерело отримання нової інформації.

Результати дослідження дозволили встановити наявність гендерних відмінностей за шкалою «Залежність від соціальних мереж» $\left(\chi^{2}=21,92 ; \mathrm{p}<0,05\right)$. Так, ознаки залежності притаманні $4,2 \%$ хлопців та 8,7\% - дівчат. У дівчат потреба в спілкуванні $\epsilon$ більш вираженою в цілому, що спонукає їх до розширення сфери взаємодії, поповнюючи іiі віртуальними друзями. До прояву активності в соціальній мережі дівчину спонукає також прагнення отримати різноманітні прояви уваги з боку чоловіків, що сприяє підвищенню самооцінки та зростанню впевненості в собі. Така форма самоствердження є для особистості більш прийнятною, ніж презентація себе в реальному житті, оскільки мережа дозволяє створити вдосконалений образ власного «Я». Особистість отримує можливість демонструвати свої кращі фото, за необхідності коректуючи їх у фотошопі, або ж взагалі використовувати чужі знімки, якщо індивід не задоволений власною зовнішністю. Можна також змінити іншу інформацію про себе, наприклад вік, рід занять тощо, створивши таким чином більш привабливий на думку особистості образ, від імені якого і здійснюється комунікація. Таким чином, створивши ідеальний образ власного «Я» та взаємодіючи 3 позиції цієї ролі з іншими, людина почувається впевнено та комфортно, що робить таке спілкування більш привабливим, ніж реальні контакти. Для прикладу наведемо такі твердження: 
«Лише в інтернеті можна змусити інших людей сприймати себе по-іншому», «Зміна справжнього образу «Я» у віртуальному світі дозволяє розкритися $з$ дещо нової сторони, проявити свої приховані риси», «Я хочу, щоб в інтернеті мене сприймали як людину більш привабливу та успішну, тому змінюю деякі свої характеристики», «Для мене інтернет - це місце, де можна отримати багато уваги з боку чоловіків».

За допомогою інтент-аналізу виокремлено такі дискурси інтернет-залежних дівчат: приховування справжнього образу (25,3\%), побудова віртуальних стосунків (30,0\%), низька самооцінка (27,8\%), фрустрованість потреби в спілкуванні (16,7\%). В інтернетзалежних хлопців виявлено такі дискурси: кіберсекс $(56,6 \%)$, невпевненість в собі $(22,4 \%)$, задоволення потреби у спілкуванні 3 особами протилежної статі $(11,6 \%)$, засіб зняти психологічну напругу $(9,4 \%)$.

Пограничні показники залежності від соціальних мереж притаманні $15,4 \%$ хлопців та 24,8\% - дівчат. Останній показник $є$ вищим, що свідчить про більшу схильність дівчат до виникнення залежності від соціальних мереж. Особливо підвладними адиктивному впливові $є$ ті особи, в яких потреба у спілкуванні $€$ фрустрованою, які не мають друзів та не можуть повною мірою реалізуватися у сфері міжособистісних стосунків. Таким чином, соціальна мережа постає альтернативним середовищем для реалізації соціальних потреб, що може призводити до витіснення реальних стосунків та формування залежності. Прикладом можуть бути такі висловлювання: «Спілкуватись в інтернеті так само цікаво, як і віч-на-віч», «Я надаю перевагу віртуальному спілкуванню, хоч маю багато друзів в реальному житті», «Жити без соціальних мереж було б не так цікаво».

Інтент-аналіз висловлювань дівчат, яким $€$ властивими пограничні ознаки залежності від соціальних мереж, дозволив виділити такі дискурси: увага з боку чоловіків (43,6\%), прагнення подобатись $(27,4 \%)$, потреба в спілкуванні $(12,5 \%)$, підвищення самооцінки $(9,7 \%)$, розширення реальних контактів $(6,8 \%)$. Здійснивши інтент-аналіз висловлювань хлопців, виділено такі дискурси: заповнення вільного часу (29,2\%), увага 3 боку дівчат $(27,4 \%)$, презентація як реального, так і віртуального «Я» $(22,8 \%)$, розвага $(20,6 \%)$. 
Відповідно, віртуальна комунікація дівчат спрямована на те, щоб сподобатись особам протилежної статі, отримати від них увагу та за рахунок цього - підвищити власну самооцінку. Натомість, хлопці вступають у віртуальну взаємодію, передусім для того, щоб приємно провести час, розважитись та презентувати себе.

Відсутність залежності спостерігається у 80,4\% хлопців та у $66,5 \%$ дівчат. Помітно, що показник хлопців є дещо вищим, що свідчить про те, що вони меншою мірою схильні до виникнення адикції від соціальних мереж, оскільки зорієнтовані не стільки на спілкування, як на конкретну діяльність, та отримують менше задоволення від обміну емоціями, думками та враженнями ніж дівчата. Для прикладу наведемо такі висловлювання: «Спілкування в інтернеті - нецікаве», «Я спілкуюсь в мережі лише для того, щоб призначити реальну зустріч», «Люблю дивитись співрозмовникові в очі, в інтернеті це - неможливо».

На основі інтент-аналізу висловлювань дівчат виділено такі дискурси: розвага (30,4\%), спілкування 3 друзями $(27,0 \%)$, обмін інформацією (15,4\%), обмін емоціями (27,2\%). Інтент-аналіз висловлювань хлопців дозволив виділити такі дискурси: обмін інформацією $(40,6 \%)$, розвага $(22,3 \%)$, спілкування 3 друзями $(25,4 \%)$, засіб провести вільний час $(11,7 \%)$.

Відповідно, дівчата використовують віртуальну комунікацію більшою мірою для обміну емоціями, а хлопці - для обміну інформацією. Спільним $є$ занурення в соціальну мережу задля спілкування як із особами, 3 якими підтримуються стосунки в реальному житті, так і 3 віртуальними друзями, 3 якими такі контакти відсутні.

\section{Висновки}

Результати теоретико-емпіричного аналізу особливостей віртуальної комунікації вказують на тенденцію до поступового витіснення безпосереднього спілкування віртуальним, що зумовлено поширенням нових інформаційних технологій та пов'язано iз загостренням міжособистісних та внутрішньоособистісних конфліктів, які $€$ наслідком суспільно-політичних змін, що відбуваються в сучасному соціумі та знижують стійкість 
особистості до дії адиктивних агентів, одним 3 яких є віртуальна реальність, що на фоні соціально-економічних зрушень здається багатьом особливо привабливою для втечі від проблем. Віртуальна комунікація найбільш активно здійснюється в контексті використання соціальних мереж, які дають змогу не лише обмінюватись інформацією, але й встановлювати нові контакти, отримувати емоційний відгук, задовольняти фрустровані потреби, що стосуються комунікативної сфери.

В осіб, що страждають на залежність від соціальних мереж, комунікативний процес набуває специфічних змін: надається абсолютна перевага віртуальному спілкуванню, при чому поступово втрачається здатність включатися у безпосередню «живу» взаємодію; комунікативна активність у мережі набуває компульсивного характеру; при встановленні контактів у мережі переважно використовується віртуальний образ, що значною мірою відрізняється від реального «Я»; спостерігається тенденція до реалізації соціально несхвалюваних тенденцій, демонструється вербальна агресія, булінг тощо.

Досліджуючи гендерні відмінності віртуальної комунікації, було встановлено, що дівчата у випадку побудови віртуальної взаємодії орієнтуються на підтримку близьких міжособистісних стосунків в мережі, тоді як хлопців більшою мірою приваблює можливість кіберсексу з різними партнершами. Спілкування дівчат також характеризується більшою емоційністю та спрямованістю на сам процес побудови стосунків, тоді як хлопці більше орієнтовані та діяльність та іiі результат. Для дівчат спілкування в соціальних мережах та отримання знаків уваги з боку осіб протилежної статі $\epsilon$ засобом підвищення самооцінки та формування впевненості в собі, натомість хлопці частіше взаємодіють в соціальній мережі від імені «ідеального Я», що перешкоджає закріпленню позитивного емоційного впливу, отриманого в мережі, в контексті реального функціонування особистості.

Враховуючи отримані емпіричні результати, а також переосмисливши нариси з лінгвістичної прагматики Ф. Бацевича (2010), які стосуються квазікомунікативних процесів в інтернетсередовищі, нами було виокремлено психолінгвістичні ознаки віртуальної комунікації, а саме: 
- психолінгвістична пресупозиція в інтернет-середовищі, яку номінуємо як особливий різновид логічного опанування віртуальною інформацією, когнітивну експлікацію фреймів за допомогою актуалізації спільного фонду знань учасників спілкування про світ, його організацію, місце людини в ньому тощо. Психолінгвістична пресупозиція у випадку здійснення людиною віртуальної комунікації в інтернет-середовищі характеризується спільним досвідом, тезаурусом, актуалізацією спільних попередніх відомостей про певне явище, подію, стан речей тощо, якими володіють комуніканти. Завдяки психолінгвістичній пресупозиції віртуальна комунікація в інтернет-середовищі створює ніби зону перетину когнітивних просторів учасників комунікації, яка звужується або розширюється у процесі інтернет-спілкування. В інтернет-середовищі психолінгвістичні пресупозиції когнітивно передують висловленню. Існування усіх можливих пресупозицій особистості формують іiі світогляд, уможливлюють більш широкий комунікативний простір. Відсутність спільних пресупозицій унеможливлює взаєморозуміння людей, значно ускладнює їх спілкування. При цьому, навпаки, носії спільних пресу позицій без будь-яких ускладнень розуміють інтернет-інформацію, яка для представників іншої лінгвокультури може здаватися абсолютно «непрозорою». Відтак, психолінгвістична пресупозиція в інтернет-спілкуванні $\epsilon$ імпліцитним компонентом смислу повідомлення (висловлення), який $\epsilon$ реальним, тому дане повідомлення (висловлення) загалом не може сприйматися як семантично аномальне або недоречне у певному просторі віртуальної комунікації;

- психолінгвістичні семантичні пресупозиції, які ми аналізуємо як певний семантичний компонент повідомлення (висловлення, судження), неістинність якого в певній конкретній ситуації перетворює повідомлення на аномальне або недоречне. Приміром, у висловленні: «Всі потужні університети України розташовані в Києві» актуальна пресупозиція «Всі університети знаходяться в Києві» є неістинною і стосується семантики, тобто відношення мовних знаків до позамовної дійсності;

- прагматична, психолінгвістично маркована пресупозиція, що $є$ компонентом повідомлення, мовленнєвого жанру, дискурсу (тексту), яка безпосередньо пов'язана із суб'єктивними чинниками інтернет-спілкування (орієнтацією в ситуаціях віртуальної 
комунікації, актуалізацією соціальних, когнітивних, гендерних тощо характеристиках учасників комунікативного акту), відсутність або незнання якого перетворює повідомлення, мовленнєвий жанр, дискурс (текст), віртуальну комунікацію загалом у недоречні нещирі, неприродні, провокаційні, такі, що не відповідають умовам їх успішності тощо.

\section{Література}

Антонова Н.В. Психология Интернета: направленность современных исследований. Журнал практического психолога. 2010. № 4. С. 17-36.

Арестова О.Н. Коммуникация в компьютерных сетях: психологические детерминанты и последствия. Вестник московского университетата. 1996. № 4. С. 14-20.

Батаєва К. Соціальна феноменологія кіберкомунікації. Соціологія: теорія, методи, маркетинг: науково-теоретичний часопис. 2011. № 1. С. 52-66.

Бацевич Ф. Нариси $з$ лінгвістичної прагматики. Львів: ПАІС, 2010. 336 с.

Белинская Е.П. Психология Интернет-коммуникации. Воронеж: МОДЭК, 2013. 185 с. Вакуліч Т.М. Психологічні чинники запобігання інтернет-залежності підлітків: дис... канд. наук: 19.00.07. Київ, 2006. 255 с.

Завьялова 3.С. Самопрезентация личности в чат-коммуникации: дисс. ... канд. наук: 09.00.11. Томск, 2011. 144 с.

Камінська О.В. Психологія інтернет-залежності: монографія. Житомир: Вид-во ЖДУ ім. І. Франка, 2015. 339 с.

Коваленко А.В. Виртуальная личность: игровые практики и самопрезентация в WEB. Науковий часопис Національного педагогічного університету імені М.П. Драгоманова. 2012. Вип. 37(61). С. 280-284.

Чионова Н.А. Социокультурные аспекты массовых коммуникаций в информационном обществе: философский анализ: дисс. ... канд. наук: 09.00.11. Москва, 2012. 149 с.

Чудова Н.В. Особенности образа «Я» жителя интернета. Психологический журнал. 2002. Т. 23. № 1. С. 113-118.

Argaman, O. (2010). Linguistic Markers and Emotional intensity. Journal of Psycholinguistic Research, 39(2), 89-99. https://doi.org/10.1007/s10936-009-9127-1

Cirelli, K.L., Dickinson, J., \& Poirier, M. (2015). Using implicit Instructional cues to influence false memory induction. Journal of Psycholinguistic Research, 44(5), 485-494. https://doi.org/10.1007/s10936-014-9301-y

\section{References}

Antonova, N.V. (2010). Psixologiya Interneta: napravlennost sovremennyx issledovanij [Psychology of the Internet: the focus of modern research]. Zhurnal prakticheskogo psixologa - Journal of Practical Psychologist, 4, 17-36 [in Russian].

Arestova, O.N. (1996). Kommunikaciya v kompyuternyx setyax: psixologicheskie determinanty i posledstviya [Communication in Computer networks: psychological 
determinants and consequences]. Vestnik moskovskogo universitetata - Bulletin of Moscow University, 4, 14-20 [in Russian].

Batayeva, K. (2011). Sotsialna fenomenolohiia kiberkomunikatsii [Social phenomenology of cyber-communication]. Sotsiolohiia: teoriia, metody, marketynh: naukovo-teoretychnyi chasopys - Sociology: the theory, methods, the marketing: scientific and theoretical journal, 1, 52-66 [in Ukrainian].

Batsevych, F. (2010). Narysy z linhvistychnoi prahmatyky [Essays on linguistic pragmatics]. Lviv: PAIS [in Ukrainian].

Belinskaya, E.P. (2013). Psixologiya Internet-kommunikacii [Psychology of Internet communication]. Voronezh: MODEK [in Russian].

Vakulich, T.M. (2006). Psykholohichni chynnyky zapobihannia internet-zalezhnosti pidlitkiv [Psychological factors preventing Internet addiction of teenagers]. Candidate's thesis. Kyiv [in Ukrainian].

Zavyalova, Z.S. (2011). Samoprezentaciya lichnosti v chat-kommunikacii [Selfpresentation of the person in chat communication]. Candidate's thesis. Tomsk [in Russian].

Kaminska, O.V. (2015). Psykholohiia internet-zalezhnosti [Psychology of Internet addiction]. Zhytomyr: Publishing House of ZhDU named after I. Franko [in Ukrainian].

Kovalenko, A.V. (2012). Virtualnaya lichnost: igrovye praktiki i samoprezentaciya $\mathrm{v}$ WEB [Virtual person: game practices and self-presentation in the WEB]. Naukovyi chasopys Natsionalnoho pedahohichnoho universytetu imeni M.P. Drahomanova - Scientific journal of the National Pedagogical University named after M.P. Dragomanov, 37(61), 280-284 [in Russian].

Chionova, N.A. (2012). Sociokulturnye aspekty massovyx kommunikacij v informacionnom obshhestve: filosofskij analiz [Sociocultural aspects of mass communications in the information society: a philosophical analysis]. Candidate's thesis. Moscow [in Russian].

Chudova, N.V. (2002). Osobennosti obraza «Ya» zhitelya interneta [The features of the image of «I» as the Internet user]. Psixologicheskij zhurnal - Psychological journal, 23(1), 113-118 [in Russian].

Argaman, O. (2010). Linguistic Markers and Emotional intensity. Journal of Psycholinguistic Research, 39(2), 89-99. https://doi.org/10.1007/s10936-009-9127-1

Cirelli, K.L., Dickinson, J., \& Poirier, M. (2015). Using implicit Instructional cues to influence false memory induction. Journal of Psycholinguistic Research, 44(5), 485-494. https://doi.org/10.1007/s10936-014-9301-y

\begin{abstract}
АНОТАЦІЯ
В статті розглянуто психологічні особливості віртуальної комунікації осіб, яким притаманна залежність від соціальних мереж. Здійснено порівняльний аналіз особливостей кіберкомунікації адиктів та інших користувачів інтернету. Проаналізовано гендерні відмінності віртуальної комунікації. Встановлено, що в сучасному суспільстві віртуальна комунікація набуває все більшого поширення у зв'язку із впровадженням новітніх інформаційних технологій. Таким чином, безпосереднє міжособистісне спілкування поступово витісняється віртуальними засобами передавання інформації. Специфріка віртуальної комунікації особливо
\end{abstract}


яскраво виявляється при використанні особистістю сочіальних мереж, що служать для підтримання контактів, пошуку однодумців, вираження емоційних станів, в тому числі і тих, що соціумом вважаються неприйнятними. Виділено психолінгвістичні ознаки віртуальної комунікації в Інтернет-середовищі, а саме: психолінгвістичні пресупозичії, психолінгвістичні семантичні пресупозичії та прагматичні, психолінгвістично марковані пресупозиції. Зазначено, що психолінгвістична пресупозиція $\epsilon$ особливим різновидом логічного опанування віртуальною інформацією, когнітивної експлікації фреймів за допомогою актуалізації спільного фонду знань учасників спілкування про світ, його організацію, місце людини в ньому тощо. Також в Інтернет-середовищі нерідко мають місце психолінгвістичні семантичні пресупозиції, які аналізуються як певний семантичний компонент повідомлення (висловлення, судження), неістинність якого в певній конкретній ситуації перетворює повідомлення на аномальне або недоречне. Також у просторі віртуальної комунікації нерідко домінувальною є прагматична, психолінгвістично маркована пресупозиція, що $\epsilon$ компонентом повідомлення, мовленнєвого жанру, дискурсу (тексту), яка безпосередньо пов'язана із суб'єктивними чинниками Інтернет-спілкування (орієнтацією в ситуаціях віртуальної комунікації, актуалізацією соціальних, когнітивних, гендерних тощо характеристиках учасників комунікативного акту), відсутність або незнання якого перетворює повідомлення, мовленнєвий жанр, дискурс (текст), віртуальну комунікацію загалом у недоречні - нещирі, неприродні, провокаційні, такі, що не відповідають умовам їх успішності тощо.

Ключові слова: віртуальна комунікація, кіберкомунікація, інтернет- спілкування, взаємодія, психолінгвістичні пресупозичії, психолінгвістичні семантичні пресу позиції, прагматичні, психолінгвістично марковані пресупозиції.

Каминская Ольга, Стежко Юрий, Глебова Людмила. Психолингвистика виртуальной коммуникации в контексте зависимости от социальных сетей

\section{АННОТАЦИЯ}

В статье рассмотрены психологические особенности виртуальной коммуникации лиц зависимых от социальных сетей. Осуществлен сравнительный анализ особенностей киберкомуникации аддиктов и других пользователей интернета. Проанализированы различия виртуальной коммуникации. Установлено, что в современном обществе виртуальная коммуникация приобретает все большее распространение в связи с внедрением новейших информационных технологий. Таким образом, непосредственное межличностное общение постепенно вытесняется виртуальными средствами передачи информации. Специфика виртуальной коммуникации особенно ярко проявляется при использовании личностью социальных сетей, служащих для поддержания контактов, поиска единомышленников, выражения эмоциональных состояний, в том числе и тех, которые социумом считаются неприемлемыми. Выделены психолингвистические характеристики 
виртуальной коммуникации в Интернет-среде, а именно: психолингвистические пресуппозиции, психолингвистические семантические пресуппозиции и прагматические, психолингвистически маркированные пресуппозиции. Отмечено, что психолингвистическая пресуппозиция является разновидностью логического освоения виртуальной информации, когнитивной экспликации фреймов с помощью актуализации общего фонда знаний участников общения o мире, его организации, месте человека в нём. Также в Интернет-среде нередко имеют место психолингвистические семантические пресуппозиции, которые анализируются как некий семантический компонент сообщения (высказывания, суждения), неистинность которого в определённой конкретной ситуации превращает сообщения на неуместное. Также в пространстве виртуальной коммуникации нередко доминирующим является прагматическая, психолингвистически маркированная пресуппозиция, которая является определённым компонентом сообщения речевого жанра, дискурса (текста). Данная пресуппозиция непосредственно связана с субъективными фракторами Интернет-общения (ориентацией в ситуациях виртуальной коммуникации, актуализацией социальных, когнитивных, гендерных и т.д. характеристик участников коммуникативного акта), отсутствие или незнание которого превращает сообщения, речевой жанр, дискурс (текст), виртуальную коммуникацию в целом в неуместные - неискренние, неестественные, провокационные, неуспешные.

Ключевые слова: виртуальная коммуникация, киберкоммуникация, интернет общение, взаимодействие, психолингвистические пресуппозиции, психолингвистические семантические пресуппозиции, прагматические, психолингвистические маркированные пресуппозиции. 